\title{
Evaluation of susceptibility of an olive progeny (Picholine $x$ Meski) to olive leaf spot disease caused by Fusicladium oleagineum
}

\author{
A. Rhouma • M. Chettaoui • S. Krid • H. Elbsir • \\ M. Msallem • M. A. Triki
}

Accepted: 31 July 2012 / Published online: 29 September 2012

(C) The Author(s) 2012. This article is published with open access at Springerlink.com

\begin{abstract}
Forty five descendants from a crossing between olive cultivar Picholine de Languedoc and the local cultivar Meski were evaluated for their susceptibility to olive leaf spot (Fusicladium oleagineum) in field and laboratory studies. Disease incidence varied greatly among the descendants and was correlated with the severity of leaf symptoms. Based on field observations and laboratory tests, the hybrids were classified into five groups: 1) very susceptible to the disease: Meski and $17 \mathrm{H}, 2)$ susceptible to the disease : 20J, 8I, 11I, 21I, 14H, 16H, 23H, 6J, 8J and 23J, 3) moderately resistant to the disease : 15I, 16I, 22I, 23I, $8 \mathrm{~K}, 13 \mathrm{H}, 18 \mathrm{H}, 22 \mathrm{H}, 9 \mathrm{~J}, 10 \mathrm{~J}, 11 \mathrm{~J}, 12 \mathrm{~J}, 14 \mathrm{~J}, 16 \mathrm{~J}, 18 \mathrm{~J}, 4)$ resistant to the disease: 21J, 12I, 13I, 18I, 19I, 9K, $10 \mathrm{~K}, 12 \mathrm{H}, 15 \mathrm{H}, 19 \mathrm{H}, 15 \mathrm{~J}$ and $22 \mathrm{~J}$, and completely resistant to the disease : cultivar Picholine and hybrids 6I and 19I. The analysis of anatomical parameters showed that the polyphenol content and composition were not correlated with disease incidence. However,
\end{abstract}

Ali Rhouma and Mayssa Chettaoui have participated equally in this work.

A. Rhouma $(\bowtie) \cdot$ M. Chettaoui $\cdot$ S. Krid $\cdot$ H. Elbsir •

M. Msallem $\cdot$ M. A. Triki

Laboratoire d'amélioration et Protection des Ressources

Génétiques de l'olivier, Institut de L'olivier de Sfax,

BP 208 Cité Mahrajène,

1082 Tunis, Tunisia

e-mail: roumaal@yahoo.fr

A. Rhouma

e-mail: ali.rhouma@iresa.agrinet.tn the cuticle thickness and the trichome density are very important physical parameters that can determine the degree of susceptibility of hybrids to the disease. The assessment method may be useful to screen olive cultivars and hybrids for Fusicladium resistance.

Keywords Fusicladium oleagineum · Hybrid · Meski · Picholine $\cdot$ Cuticle $\cdot$ Trichome

\section{Introduction}

Tunisia is the most important olive-growing country of the southern Mediterranean region where over $30 \%$ of its cultivated land is dedicated to olive growing (1.68 million ha). The annual production is recently estimated to 750,000 $\mathrm{t}$ of olives in 2009 (COI 2011).

Tunisia has an inheritance rich of table olive cultivars with about 24 cultivars, of which 20 are Tunisian and the others introduced. Among the local cultivars, Meski is the most important table olive cultivar cultivated in the country because of the very good taste of its fruits. Unfortunately, this cultivar has certain problems owing to its low productivity, its self sterility, its late entry in production and its alternate bearing. Moreover, this cultivar is very susceptible to olive leaf spot also known as olive scab, olive leaf spot and bird's-eye spot (Graniti 1993; Shabi et al. 1994; Trapero and Blanco 2008; Viruega et al. 1997; Obanor et al. 2008; Vossen 2004) caused by Fusicladium oleagineum. This foliar disease is very common in the humid regions of Tunisia. Infected 
trees show defoliation of leaves which result in poor twig growth and poor fruit set, and great damage to plantations (Gonzalez-Lamothe et al. 2002). Infection is normally associated with high humidity and cool winter temperatures and low light conditions (cool and low light), where high temperatures restrict spore germination and growth (Al-khatib et al. 2010).

The use of protective fungicides, particularly copper compounds, against olive scab is a customary practice in growing olives (Teviotdale et al. 1989). Nowadays, there is a tendency towards reducing the number of active ingredients, especially those which are more dangerous to human and the environment, and to the search for new and alternative ways of control of the plant diseases. Application of copper-based fungicides is now the main method of olive leaf spot control in Tunisia and other olive growing countries. However, although there is a lower risk of pathogens developing resistance to copperbased fungicides since they have multi-site activity, some cases of resistance have been reported in bacterial diseases (Vanneste et al. 2003; Carisse et al. 2000). Washington et al. (1992) have reported that copper hydroxide has been ineffective on grey mould of strawberries. Additionally, copper compounds affect the disturbance of plant metabolism following $\mathrm{Cu}$ accumulation in the soil (Obanor et al. 2008; Zine El Aabidine et al. 2010).

Use of resistant olive cultivars is the most effective, economically feasible and ecologically sustainable means of controlling olive leaf spot. In this context, a breeding program was initiated in 1993 in a project entitled "olive breeding" (supported by the International Olive Council) (Fontanazza and Baldoni 1990). The cultivar Meski was crossed with the resistant cv. Picholine Languedoc and a collection of 45 hybrids are now being grown in the region of Oued Souhil (Nabeul). The aim of the present study was to evaluate the susceptibility of the 45 hybrids to olive leaf spot and to study the physical and chemical factors involved in the resistance to the fungal disease.

\section{Materials and methods}

Field site

The field site is located at the experimental station of the National Institute of Agricultural Engineering and Forestery of Tunisia (INGREF) located at Oued Souhil in the region of Nabeul (latitude NR 36 (27' 22", E10 longitude $\left(42^{\prime} 02^{\prime \prime}\right)$. This region is characterized by a humid weather climate that favours olive leaf spot. The station has a collection of the principal Tunisian and foreign cultivars of olive, such as: Chemlali, Chetoui, Manzanille, Picholine and Meski, and a collection of 365 hybrids from crosses of Meski with several pollinating local and foreign cultivars.

Olive tree hybrids studied

The hybrids studied in this project were a population of 45 descendants resulting from a crossing between Picholine de Languedoc and the local cultivar Meski. The descendants were planted in Oued Souhil (Nabeul) in 1993. Letters represent the lines in the orchard and the numbers indicate the trees.

- $12 \mathrm{H}-13 \mathrm{H}-14 \mathrm{H}-15 \mathrm{H}-16 \mathrm{H}-17 \mathrm{H}-18 \mathrm{H}-19 \mathrm{H}-22 \mathrm{H}-$ $23 \mathrm{H}$

- 6I-8I-11I-12I-13I-14I-15I-16I-18I-19I-21I22I-23I

- $6 \mathrm{~J}-8 \mathrm{~J}-9 \mathrm{~J}-10 \mathrm{~J}-11 \mathrm{~J}-12 \mathrm{~J}-14 \mathrm{~J}-15 \mathrm{~J}-16 \mathrm{~J}-18 \mathrm{~J}-20 \mathrm{~J}-$ $21 \mathrm{~J}-22 \mathrm{~J}-23 \mathrm{~J}$

- $8 \mathrm{~K}-9 \mathrm{~K}-10 \mathrm{~K}$

Evaluation of hybrid susceptibility in the field

Leaf sampling

A total of 120 leaves were taken randomly from each hybrid with 20 leaves per branch on six branches selected in various directions. The leaves were placed in plastic bags and taken to the laboratory in order to determine the latent and visible infections.

The leaves were sampled at the end of summer to determine the number of latent infections and in the spring for the number of lesions.

\section{Latent infection}

Latent infections were determined according to the method of Shabi et al. (1994). To determine latent infection, leaves were dipped in $5 \% \mathrm{NaOH}$ for $20 \mathrm{~min}$ (Shabi et al. 1994) and examined for characteristic black spots.

\section{Visible infection}

A total of 120 leaves were taken during spring (at the beginning of April). Samples of branches $20-25 \mathrm{~cm}$ in 
length were taken from different parts of the olive tree. The samples were placed in plastic bags and brought back to the laboratory in order to determine the percentage of infected leaves. The severity of peacock spot was determined by leaf coverage with lesions, the number of lesions on each leaf, and the diameter of lesions.

Evaluation of hybrid susceptibility in the laboratory

\section{Inoculum preparation}

Conidia of $F$. oleagineum used in the inoculation were obtained from diseased leaves of olive tree cv Meski. The infected leaves were dried at ambient temperature for 2 weeks and then stored at $5^{\circ} \mathrm{C}$ in darkness (LópezDoncel et al. 2000).

To obtain conidial suspensions, the infected leaves were agitated in sterile distilled water for $2 \mathrm{~h}$ at $80 \mathrm{rpm}$ at ambient temperature. The conidial suspension was then filtered to eliminate vegetable matter. The concentration of the conidial suspension was adjusted to $10^{5}$ conidia $\mathrm{ml}^{-1}$ using a Malessez cell.

\section{Leaf inoculation}

To evaluate the cultivar susceptibility to olive leaf spot, detached leaves of each cultivar were used. Detached leaves were surface-disinfected with tissue paper moistened with ethanol for $30 \mathrm{~s}$ and placed in plastic bugs containing sterile distilled water to maintain a high relative humidity. Leaves were inoculated with $5 \mu \mathrm{l}$ of a conidial suspension of $F$. oleagineum $\left(1.5 \times 10^{5}\right.$ conidia $\left.\mathrm{ml}^{-1}\right)$ following the method of López-Doncel et al. (2000). Control leaves were inoculated with sterile distilled water. The plastic bags were closed and incubated at a temperature of $15^{\circ} \mathrm{C}$ and a relative humidity of $90 \%$ in the dark. The incidence ( $\%$ of infected leaves) and the severity (number of spots per leaf) were determined after 15 days.

\section{Histological studies}

\section{Measurements of trichome density}

Histological measurements of tissues were made on ten leaves obtained from each cultivar and hybrid. Cross-sections of fresh leaf material were prepared for microscopic examination. Trichome density (number per unit leaf area) and diameter were measured in artificial replicas of polish (colodium) applied to the abaxial surface of ten leaves per treatment. Trichome density was measured according to Larkin et al. (1996) from the upper leaf surface. The leaf discs (area$0.29 \mathrm{~cm}^{2}$ ) were taken from the centre of the leaf blade and counted for the number of trichomes under a compound light microscope. Trichome density was calculated as the trichome number per disc area.

\section{Cuticle thickness}

The leaves were cut transversally using a sharp blade with a regular movement and without sawing to keep leaf structures intact. The cuts were made perpendicular to the axis of the leaf. The cuttings were stained with carmine after a preliminary dipping in bleach. The cut pieces were subsequently washed with sterile distilled water until obtaining clear water. Then two to three drops of iodine green were deposited on the cut piece which was followed by washing with water. The histological structure of the cut surface were observed using a microscope. The total thickness of the leaf and the thickness of the cuticle were measured.

Phenolic compounds content and identification

\section{Polyphenols content}

Phenolic compounds were extracted according to the method of Mau et al. (2001). One hundred mg of leaf powder were mixed with $10 \mathrm{ml}$ of methanol. After $20 \mathrm{~h}$ of agitation at a temperature of $25^{\circ} \mathrm{C}$ in the darkness, the mixture was centrifuged for $10 \mathrm{~min}$ at $2,000 \mathrm{rpm}$. The extract was stored at $4^{\circ} \mathrm{C}$ in the dark.

The proportioning of the phenolic compounds was performed according to the method of Folin Ciocalteu (Singleton et al. 1999). $500 \mu$ of the extract was diluted at $1 / 10$ with methanol and mixed with $2.5 \mathrm{ml}$ of Folin $(10 \%)$ to which $2 \mathrm{ml}$ of $\mathrm{NaCO}_{3} 7.5 \%$ were added. The mixture was left to incubate for $90 \mathrm{~min}$ and the absorbance was determined at $760 \mathrm{~nm}$.

The standard used in this work was gallic acid, prepared at concentrations varying from 5 to $100 \mathrm{mg}^{-1}$. The content of polyphenols was expressed as $\mathrm{mg}$ of equivalent of gallic acid per gram of dry matter (mg EAG g ${ }^{-1} \mathrm{Ms}$ ). 


\section{Polyphenol identification}

Phenolic compounds were extracted according to the method of Bouaziz and Sayadi (2005). A mixture of methanol and water $(300 \mathrm{ml}, 80: 20 \mathrm{v} / \mathrm{v})$ was added to $60 \mathrm{~g}$ of leaf powder and the mixture was agitated in the darkness for $20 \mathrm{~h}$. Thereafter, the solution was filtered with the filter paper $\mathrm{GF} / \mathrm{F}$. The extract was placed in a vacuum at $40^{\circ} \mathrm{C}$ to desiccate it. The residue obtained was dissolved in $5 \mathrm{ml}$ of methanol, and then preserved in pyrex flasks at $0^{\circ} \mathrm{C}$ in the darkness before chromatographic analysis.

The qualitative analysis of the phenolic compounds was carried out by high performance liquid chromatography coupled to mass spectrometry. The apparatus used (Shimadzu) was composed of a pump LLC-10ATvp and a detector UV SPD-10 Avp. The column used for the analysis of polyphenols was a C-18 $(4.6 \times 250 \mathrm{~mm})$ Shim-pack VPODS. The elutants were detected at $280 \mathrm{~nm}$ with the temperature maintained at $40{ }^{\circ} \mathrm{C}$. The mobile phase was phosphoric acid with $0.1 \%$ in water (A) and the acetonitrile with $70 \%$ in water (B) for a duration of $50 \mathrm{~min}$. The conditions of elution of the phenolic compounds were: 0-25, $1025 \% \mathrm{~B}$; 25-35 min, 25-80\% B; 35-37 min, 80,100\% B, $37-40 \mathrm{~min}, 100 \% \mathrm{~B}$. The washing and the reconditioning of the column (40-50 min) were carried out with a gradient flux field $100-10 \% \mathrm{~B}$. The flow was $0.6 \mathrm{ml} \mathrm{min}{ }^{-1}$ with a volume of injection of $50 \mu \mathrm{l}$. The identification and the quantification of the phenolic compounds from the leaves of the hybrids and cultivars were based on their spectra and their times of retention in comparison with the phenolic standards available (Bouaziz and Sayadi 2005).

Fig. 1 Percentage of latent infection of hybrid leaves collected from Oued Souhil at the experimental field. Bars indicates the standard deviation
Data analysis

Latent and visible infections were based on a total of 120 leaves taken randomly from each hybrid with 20 leaves per branch on six branches selected in various directions. The sampling was repeated three times and data were transformed to meet the requirement for normal distribution. The results were analysed using analysis of variance (ANOVA) and Duncan's multiple range test (Software SPSS version 18).

Principal components analysis (CPA) was done using MVSP software. The dendrogram was created by using the UPGMA method and Euclidian distances using the software NTSys (Rohlf 1998).

\section{Results}

Evaluation of latent infection of hybrids in the field

The results shown in Fig. 1 reveal an important variation in the susceptibility of the hybrids to the disease. The analysis of variance and the means comparison revealed significant differences between the hybrids. Indeed, the cultivar Picholine and hybrid 6I were the most resistant to the disease since no latent infections were observed. The hybrids 18I, 19I, 12I, 13I, 9K, 10K and 12H were less resistant with the percentages of latent infection not exceeding $5 \%$. However, cv. Meski and the hybrids 14I, $21 \mathrm{I}, 14 \mathrm{H}, 17 \mathrm{H}, 16 \mathrm{H}, 18 \mathrm{H}, 6 \mathrm{~J}, 8 \mathrm{~J}, 20 \mathrm{~J}$ and $23 \mathrm{~J}$ were the most susceptible to the disease, with the percentages of latent infections ranging from $20 \%$ to $30 \%$.

Evaluation of visible infection of hybrids in the field

Results presented in Fig. 2 show that cv. Picholine and hybrid 6I were the most resistant in the studied

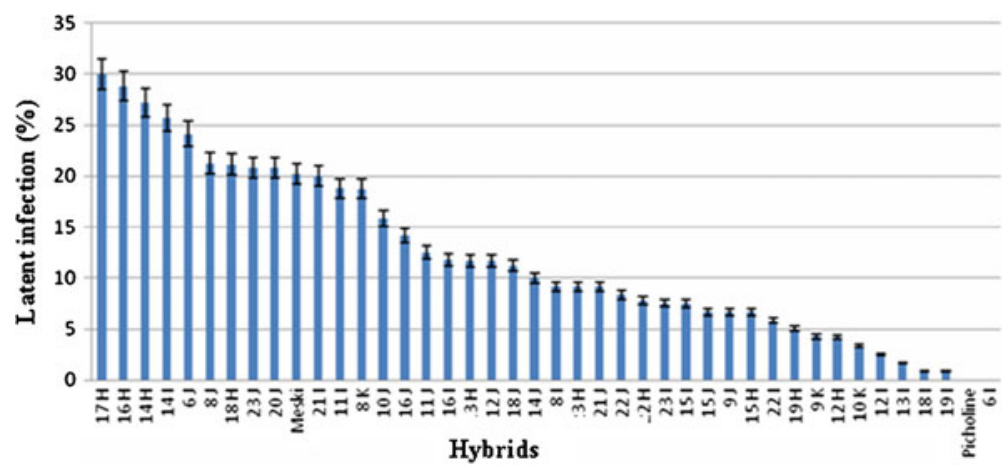


Fig. 2 Percentage of visible infection on hybrid leaves collected from Oued Souhil at the experimental field. Bars indicates the standard deviation

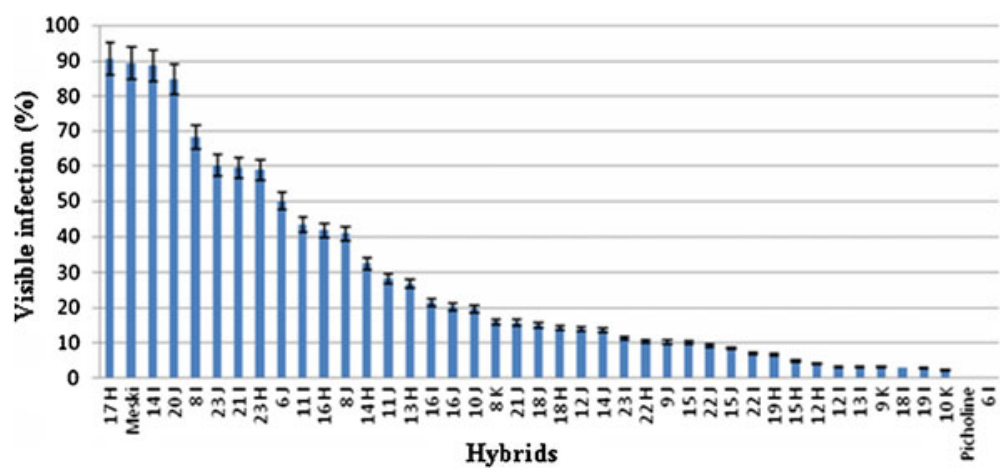

collection since no symptoms were observed, even in spring when environmental conditions were very favourable for the development of the disease. The hybrids 12I, 13I, 18I, 19I, 22I, 9K, 10K, 12H, 15H, $19 \mathrm{H}, 15 \mathrm{~J}$ and $22 \mathrm{~J}$ were less resistant to the disease since the percentages of infection did not exceed $10 \%$. However, cv. Meski and hybrids 14I and 17H were very susceptible to the disease since the percentages of infected leaves were about $90 \%$. These hybrids presented the highest number of lesions per leaf as compared to the other hybrids (Fig. 3). The mean number of lesions per leaf was $8.35,8.63$ and 9.58 spots/leaf, respectively for cv. Meski and hybrids $14 \mathrm{I}$ and $17 \mathrm{H}$. The lesions on the leaves of cv. Meski had the largest diameters $(6 \mathrm{~mm})$ (data not shown).

The area of the leaf occupied by lesions was highest in cv. Meski and hybrids 17 (Fig. 4) and confirmed their high susceptibility to the disease.

Evaluation of susceptibility of hybrid leaves in the laboratory

The evaluation of the susceptibility of hybrids in the laboratory showed that the typical symptoms of inoculated leaves started to appear on cv. Meski and the two highly susceptible hybrids $14 \mathrm{I}$ and $17 \mathrm{H}$. The characteristic lesions appeared 5 weeks after inoculation.

The results presented in Fig. 5 showed that there was an important difference between the percentages of infected leaves of the hybrids. A positive and significant correlation was observed between the results obtained in the laboratory and the field (Fig. 6). Indeed, only the hybrids 13I, 19I, 22I, 10K, $14 \mathrm{H}, 23 \mathrm{H}$ and $15 \mathrm{~J}$ were shown to be more susceptible in the laboratory than in the field.

Phenolic compounds content

The content of phenolic compounds varied among the hybrids. For example, the leaves of hybrid $23 \mathrm{H}$ contain the lowest content polyphenols $(26.25 \mathrm{mg}$ EAG $\left.\mathrm{g}^{-1} \mathrm{Ms}\right)$. However, hybrids 6I, 19I, 22I, $8 \mathrm{~K}$ and $13 \mathrm{H}$ had the highest content of polyphenols, reaching $100 \mathrm{mg} \mathrm{EAG} \mathrm{g}^{-1} \mathrm{Ms}$. The phenolic content registered for the two parents Meski and Picholine were 71,63 and 54,08 $\mathrm{mg} \mathrm{EAG} \mathrm{g}^{-1} \mathrm{Ms}$.
Fig. 3 Number of lesions per leaf on hybrid leaves collected from Oued Souhil at the experimental field. Bars indicates the standard deviation

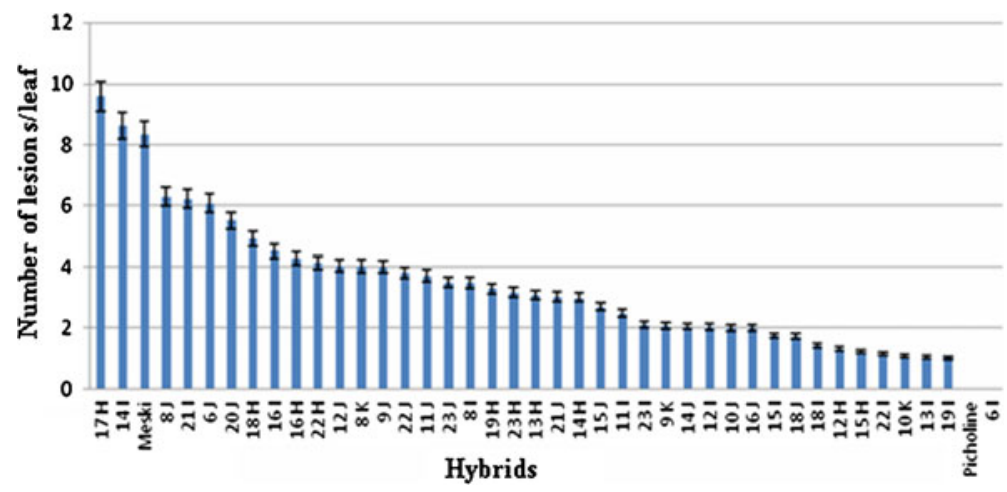


Fig. 4 Area of leaf covered by lesions of olive leaf spot on hybrids leaves collected from Oued Souhil at the experimental field. Bars indicates the standard deviation

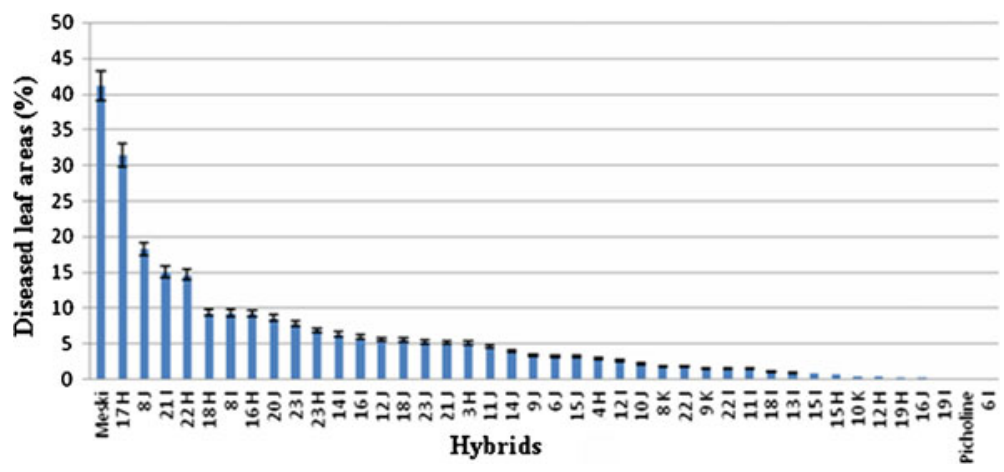

The correlation between the polyphenol content and the percentage of infection was not significant $(r=0.068, P>0.05)$.

Identification of phenolic compounds

Identification of phenolic compounds of the two parents cvs. Meski and Picholine (Fig. 7) showed the presence of a high peak which corresponded to oleuropein. The parents cvs. Meski and Picholine had similar patterns in their composition of phenolic metabolites and a very similar profile of oleuropein content (3.766 mg ml $\mathrm{md}^{-1}$ and $3.616 \mathrm{mg} \mathrm{ml}^{-1}$ ).

Trichome size and density

Measurements of the size of trichomes showed a variation in their diameter among the hybrids that ranged between 88 and $135 \mu \mathrm{m}$. The parent cv. Meski and the hybrids $17 \mathrm{H}, 15 \mathrm{~J}, 22 \mathrm{I}$, had the smallest sizes of trichomes as compared to the other hybrids where the diameters were less than $90 \mu \mathrm{m}$. The trichomes of $\mathrm{cv}$. Picholine and hybrids 6I, 19I, 10K had the highest diameter, exceeding $125 \mu \mathrm{m}$. Hybrids 14I, 17H, 8J and parent cv. Meski had the lowest densities of trichome (10 trichomes $/ \mathrm{mm}^{2}$ ); however, the resistant parent $\mathrm{cv}$. Picholine and the resistant hybrids 6I, 12I, 13I, 15I, 18I, 19I, 9K, 12H and 22J had trichome densities that varied between 20 and 28 trichomes $/ \mathrm{mm}^{2}$ (Fig. 8).

The trichome density was negatively correlated with the percentage of infection $(r=0.60, p<0.05)$. However there was no correlation between the size of trichomes and the percentage of infection $(r=0.3$, $p>0.05$ ).

\section{Cuticle thickness}

The thickness of the cuticle measured for the studied hybrids varied between 5 and $10 \mu \mathrm{m}$ (Fig. 9). Statistical analysis showed a significant difference between the different hybrids in the collection. The very susceptible hybrids $(17 \mathrm{H}$, and $20 \mathrm{~J})$ and the parent cultivar cv. Meski had the thinnest cuticle (5-6 $\mu \mathrm{m})$, whereas the resistant hybrids 6I, 22I, 23I, 9K, 10K, 19H, 22H, 9J, 14J, 15J, and cv. Picholine had thicker cuticles $(>9 \mu \mathrm{m})$.

The cuticle thickness was significantly and negatively correlated with the percentage of infected leaves in the field $(r=0.86 p<0.05)$.
Fig. 5 Percentage of infection on detached hybrids leaves inoculated with Fusicladium oleagineum. Bars indicates the standard deviation






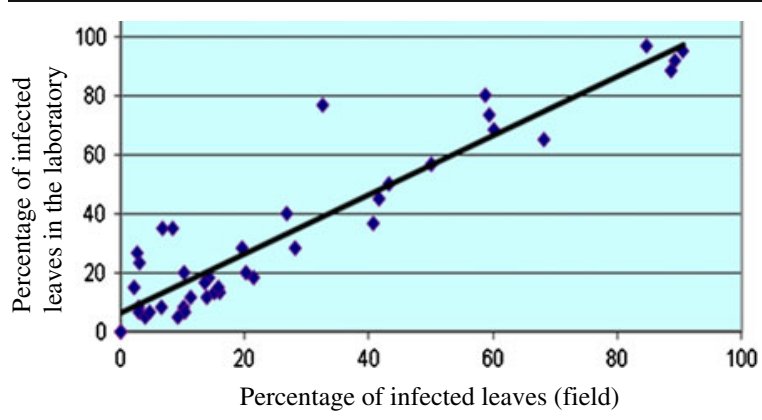

Fig. 6 Relationship between of percentage of infected leaves of hybrid in the field and in the laboratory

\section{Discussion}

Genetic resistance represents currently the best effective means to control this disease (Anton and Laborda 1989). In order to introduce resistance to Fusicladium oleagineum in the local Tunisian cultivar, a cross has been made since 1993 between the susceptible cultivar "Meski" and the resistant cultivar "Picholine du Languedoc", a cultivar of French origin

The collection of 45 hybrids has been studied in order to identify the resistant descendants and determine the factors that could be involved in the resistance to the fungus.
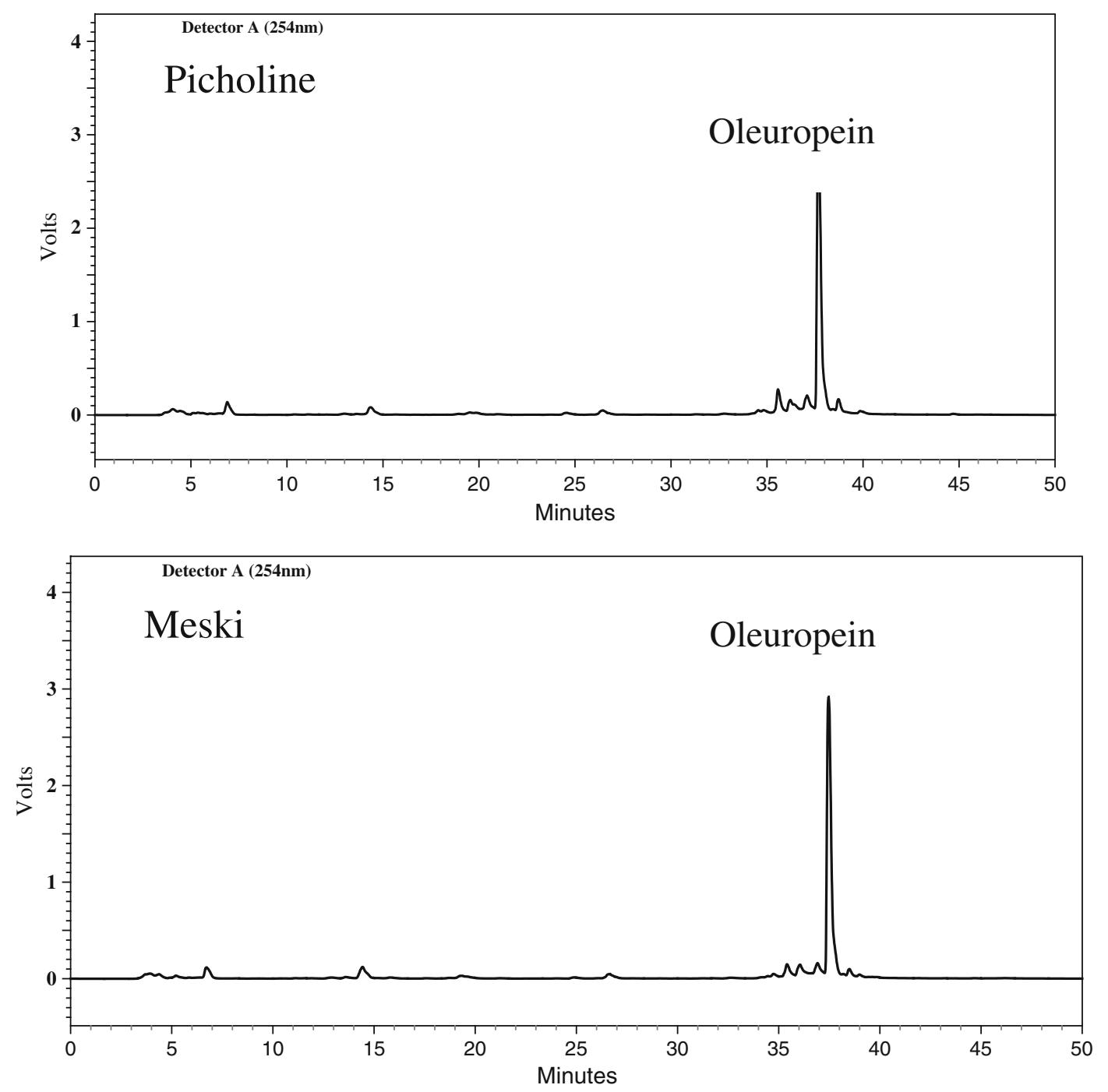

Fig. 7 Qualitative analysis of phenolic compounds of cvs. Meski and Picholine 
Fig. 8 Density of trichomes of hybrid leaves collected from Oued Souhil experimental field. Bars indicates the standard deviation

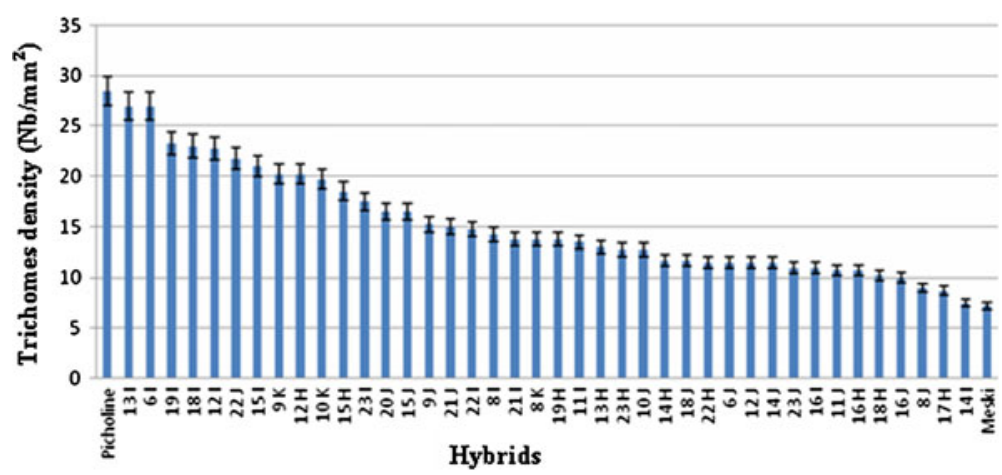

In the absence of favourable conditions for the disease, infection by the pathogen is latent without any visible symptoms for a long period. During this period, the detection of the disease was based on the reaction to a solution of sodium hydroxide $(5 \%)$. The leaves dipped in this solution generate the appearance of black spots due to the reaction of the alkaline solution with the phenolic compounds produced in the penetration site of the pathogen (Benitez et al. 2005): an oxidation of these compounds which accumulate on the lesion in response to infection (Roca et al. 2007).

The determination of latent infection revealed variability among the hybrids with the percentages of infected leaves varying between 0 and $30 \%$. Some hybrids did not present any spotting, or only some leaves were infected (6I, 18I and 19I), and consequently are regarded as resistant to the disease. However, according to Benitez et al. (2005) the evaluation of susceptibility cannot based on the latent infections and must be done using the visible infections. Therefore, the determination of visible infection during the spring (April) revealed a high variability in susceptibility of the hybrids to the disease. Based on the percentages of infested leaves, one third of the hybrid collection was considered to be resistant since the percentage of infected leaves did not exceed $10 \%$. Among these hybrids, line 6I was considered as very resistant since no spotting was observed. It seems that the parent Picholine has transferred all the resistant genes to the hybrid 6I. The evaluation of susceptibility of hybrids in the laboratory demonstrated the same results as found in the field and this positive correlation has been reported by Rallo et al. (2005) and Moral et al. (2005). However, some hybrids (13I, 19I, 22I, $10 \mathrm{~K}, 14 \mathrm{H}, 23 \mathrm{H}$, and $15 \mathrm{~J}$ ) were found to be more susceptible in the laboratory than in the field due to the differences in temperature and humidity. According to Trapero and Blanco (2008), the principal cause of this difference is due to the effect of the environmental conditions (temperature, $\mathrm{RH}$ and light). In the laboratory, the temperature and relative humidity are optimal and very favourable for the development of the disease, while in the field, several other factors influence the development of the disease.

According to these results, resistance to Fusicladium oleagineum is determined by several genes. Benitez et al. (2005) demonstrated that olive resistance to the disease is the result of an active defence response and that this active defence is genotype dependent. These authors observed higher constitutive expression of defence genes in the resistant cultivar
Fig. 9 Cuticle thickness on hybrid leaves collected from Oued Souhil experimental field. Bars indicates the standard deviation

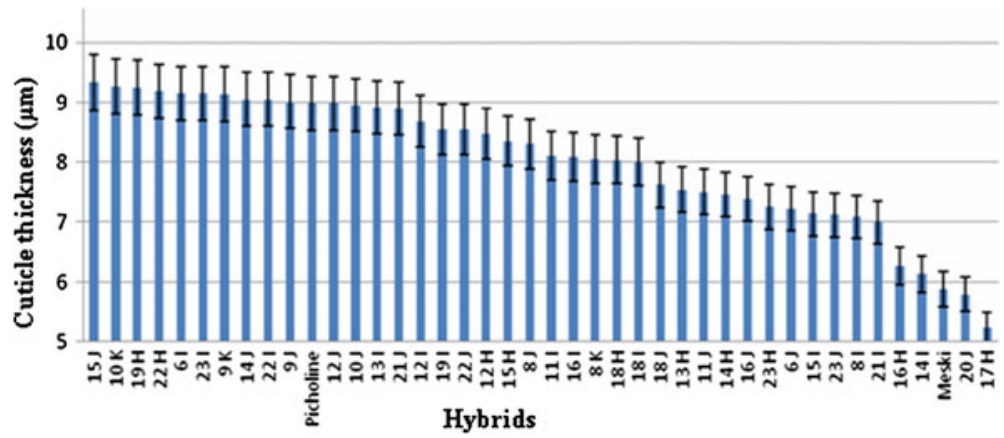


and a faster and stronger induction in gene expression after infection. They identified 162 cDNA fragments corresponding to transcripts that showed altered abundance during the defence response of a resistant cultivar to the fungal disease.

In order to determine the factors involved in the resistance to $F$. oleagineum some physical and biochemical parameters were analysed. Results showed that phenolic compounds content was not correlated with the susceptibility to the disease, confirming the results obtained by Rahioui et al. (2009) and Zine El Aabidine et al. (2010). According to these authors, the qualitative analysis of polyphenols using LC-MS showed no specific compounds related to the resistance.

Our results showed that the abundant phenolic compound found is oleuropeine. Several reports demonstrated that extract of the olive-tree is dominated by oleuropein, rutin, luteolin-7-glucoside, versbacoside, tyrosol, apigenin, vanillin, diosmetin, rutin and acide vanillique verbascoside (Bianco and Uccella 2000; Japón-Luján et al. 2006).

Oleuropein, tyrosol, hydroxytyrosol and rutin display a fungicidal effect (Baidez et al. 2007; Pereira et al. 2007). The derivatives of oleuropein, like oleuropein glucoside, seems to be implied in the defence of the olive tree by inhibiting the pectinases of F. oleagineum (Graniti 1993) and by constituting a precursor of phytoalexins (Uccella 2000), extremely toxic molecules induced in response to pathogen infection (El Modafar et al. 1995, 1999). The derivative nonglucosidic form (oleuropein aglycone) of oleuropein expresses antioxidant activity (Galli and Visioli 1999) and great cytotoxicity (Babich and Visioli 2003). Therefore, the oleuropein aglycone could play an important role in the hypersensitive reaction frequently associated with leaf defence in response to pathogen challenge (Lam et al. 2001). According to Zine El Aabidine et al. (2010), tyrosol and its derivatives were associated with constitutive resistance, whereas oleuropein and rutin were associated with induced resistance.

Analysis of the leaf cuticles of each hybrid indicated a variation in the trichome density. Thus resistant hybrids were characterised by a high number of trichomes in comparison with susceptible cultivars. A high correlation between trichome density and plant resistance to pathogens has been reported (Menendez Sevillano et al. 1997; Mmbaga and Steadman 1990 and Zaiter et al. 1990). It is generally believed that pubescent leaves will be more resistant against pathogens, pests and drought than less pubescent ones of the same species due to a mechanical restriction to pathogen activities caused by a high density of trichomes (Levin 1973). Trichomes are important structural barriers and components of resistance and are also sites for accumulation of secondary metabolites that may act as defensive, repellent or toxic compounds (Stenglein et al. 2005).

The thickness of cuticle was found to be an important factor that stops the invasion of leaves by the pathogen. Indeed, a negative and significant correlation was obtained between the thickness of the cuticle and the susceptibility of hybrids to the disease. Several works have reported that the thickness of the cuticle varies considerably among the cultivars in the same species (Jeffree 2006). To the best of our knowledge this is the first report of the implication of the cuticle thickness in the mechanism of resistance to $F$. oleagineum. The cutin of the cuticle may play a key role in leaf protection because it is barrier against the entry of the fungus

Our results showed that cv. Picholine and hybrid 6I are totally resistant to the disease and therefore could be used to replant orchards mainly in the humid regions where the environmental conditions are favourable to olive leaf spot. Furthermore, cv. Picholine, a green table olive, is highly productive. These reasons might justify the inclusion of this line in breeding programmes for resistance to olive leaf spot.

Acknowledgment The authors would like to thank Mr. Khaled Ouertani (Institut de l'Olivier) for his excellent technical assistance. This research was supported by funds of the project "bilateral control Project of main foliar diseases of olive (A/018552/08)".

Open Access This article is distributed under the terms of the Creative Commons Attribution License which permits any use, distribution, and reproduction in any medium, provided the original author(s) and the source are credited.

\section{References}

Al-Khatib, M., Alhussaen, K., El-Banna, N., \& Zyadeh, M. (2010). Biological control of olive leaf spot (peacock spot disease) caused by Cycloconium oleaginum (Spilocea oleaginea). Journal of Microbiology and Antimicrobials, 2(6), 64-67.

Anton, F. A., \& Laborda, E. (1989). Estudio de la susceptibili$\mathrm{dad} / \mathrm{resistencia} \mathrm{de} \mathrm{variedades} \mathrm{del} \mathrm{olivo} \mathrm{(Olea} \mathrm{europea} \mathrm{L.)} \mathrm{al}$ patógeno Cycloconium oleagineum Cast. (Spilocaea 
oleaginae Hugh). Boletin de Sanidad Vegetale Plagas, 4, 385-403.

Babich, H., \& Visioli, F. (2003). In vitro cytotoxicity to human cells in culture of some phenolics from olive oil. Farmaco, $58,403-407$.

Baidez, A. G., Gomez, P., Del Rio, J. A., \& Ortuño, A. (2007). Dysfunctionality of the xylem in Olea europaea L. plants associated with the infection process by Verticillium dahliae Kleb. Role of phenolic compounds in plant defense mechanism. Journal of Agricultural and Food Chemistry, 55, 3373-3377.

Benitez, Y., Botella, M. A., Trapero, A., Alsalimya, M., Cabellero, J. L., Dorado, G., \& Munoz-Balnco, J. (2005). Molecular analysis of the interaction between Olea europaea and the biotrophic fungus Spilocaea oleagina. Molecular Plant Pathology, 6(4), 425-438.

Bianco, A., \& Uccella, N. (2000). Biophenolic components of olives. Food Research International, 33, 475-485.

Bouaziz, M., \& Sayadi, S. (2005). Isolation and evaluation of antioxidants from leaves of a Tunisian cultivar olive tree. European Journal of Lipid Science and Technology, 107, $118-125$.

Carisse, O., Ouimet, A., Toussaint, V., \& Philion, V. (2000). Evaluation of the effect of seed treatments, bactericides, and cultivars on bacterial leaf spot of lettuce caused by Xanthomonas campestris pv. vitians. Plant Disease, 84(3), 295-299.

COI (2011). XVII session extraordinaire du conseil des membres, Istamboul Turquie, Juillet 2011.

El Modafar, C., Clérivet, A., Vigouroux, A., \& Macheix, J. J. (1995). Accumulation of phytoalexins in leaves of plane tree (Platanus spp.) expressing susceptibility or resistance to Ceratocystis fimbriata f. sp. platani. European Journal of Plant Pathology, 101, 503-509.

El Modafar, C., Tantaoui, A., \& El Boustani, E. (1999). Time course accumulation and fungitoxicity of date palm phytoalexins towards Fusarium oxysporum f. sp. albedinis. Journal of Phytopathology, 147, 477-484.

Fontanazza, G. \& Baldoni, L. (1990). Proposta per un programma di miglioramento gentico dell' olivo. Olivae, 34, 32-39.

Galli, C., \& Visioli, F. (1999). Antioxidant and other activities of phenolics in olives/olive oil, typical components of the Mediterranean diet. Lipids, 34, 23-26.

Gonzalez-Lamothe, R., Segura, R., Trapero, A., Baldoni, L., Botella, M. A., \& Valpuesta, V. (2002). Phylogeny of the fungus Spilocaea oleagina, the causal agent of peacock leaf spot in olive. FEMS Microbiology Letters, 210, 149155.

Graniti, A. (1993). Olive scab: a review. EPPO Bulletin, 23, 377-384.

Japón-Luján, R., Luque-Rodríguez, J. M., \& Luque de Castro, M. D. (2006). Dynamic ultrasound-assisted extraction of oleuropein and related biophenols from olive leaves. Journal of Chromatography, 1108(1), 76-82.

Jeffree, C. E. (2006). The fine structure of the plant cuticle. In M. Riederer \& C. Müller (Eds.), Biology of the plant cuticle (pp. 11-125). Oxford: Blackwell Publishing.

Lam, E., Kato, N. \& Lawton, M. (2001). Programmed Cell death, mitochondria and the plant hypersensitive response. Nature, 411, 848-853.
Larkin, J. C., Young, N., Prigge, M., \& Marks, M. D. (1996). The control of trichome spacing and number in arabidiopsis. Development, 122, 997-1005.

Levin, D. A. (1973). Role of trichomes in plant defence. The Quarterly Review of Biology, 48, 3-15.

López-Doncel, L. M., Viruega-Puente, J. R., \& Trapero-Casas, A. (2000). Respuesta del olivo a la inoculacion con Spilocaea oleagina, agente del repilo. Boletin de Sanidad Vegetale Plagas, 26, 349-363.

Mau, J. L., Chao, G. R., \& Wu, K. T. (2001). Antioxidant properties of methanolic extracts from several ear mushrooms. Journal of Agricultural and Food Chemistry, 49, 5461-5467.

Menendez Sevillano, M. C., D’Ambrogio, A., Panadero Pastrana, C., \& Sierra, E. (1997). Resistance to rust caused by foliar pubescence in Argentinean common bean cultivars. Annual Report of the Bean Improvement Cooperative, 40, 108-109.

Mmbaga, M. T., \& Steadman, J. R. (1990). Adult plant rust resistance and leaf pubescence on dry beans. Annual Report of the Bean Improvement Cooperative, 33, 6162.

Moral, J., Ávila, A., López-Doncel, L. M., Alsalimiya, M., Oliveira, R., Gutiérrez, F., Navarro, N., Bouhmidi, K., Benali, A., Roca, L., \& Trapero, A. (2005). Resistencia a los Repilos de distintas variedades de olivo. Vida Rural, 208, 34-40.

Obanor, F. O., Jaspers, M. V., Jones, E. E., \& Walter, M. (2008). Greenhouse and field evaluation of fungicides for control of olive leaf spot in New Zealand. Crop Protection, 27, 1335-1342.

Pereira, J. A., Oleivia, I., Sousa, A., Valentao, P., Andrade, P. B., Ferreira Isabel, C. F. R., Ferreres, F., Bento, A., Seabra, R., \& Estevinho, L. (2007). Walnut (Juglans regia L.) leaves: Phenolic compounds, antibacterial activity and antioxidant potential of different cultivars. Food and Chemical Toxicology, 45(2007), 2287-2295.

Rahioui, B., El-Aabidine, A. Z., Baissac, Y., El-Boustani, E., Khadari, B., Jay Allemand, C., El-Modafar, C. (2009). Phenolic compounds of olive-tree leaves and their relationship with the resistance to the leaf-spot disease caused by Spilocaea oleaginea. 5(2), 204-214.

Rallo, L., Barranco, D., Caballero, J. M., Del Río, C., Martín, A., Tous, J., \& Trujillo, I. (2005). Las variedades de olivo cultivadas en España. Consejería de Agricultura y Pesca, Ministerio de Agricultura, Pesca y Alimentación. Madrid: Ediciones Mundi-Prensa.

Roca, L. F., Juan, M. M., Jose, R. V., Arantxa, A., Rodrigues, O., Trapero, A. (2007). Copper fungicides in the control of olive diseases. FAO Olive Network (2007).

Rohlf, F. J. (1998). NTSYS-PC numerical taxonomy and multivariate analysis system version 2.01. Netauket: Exeter Software.

Shabi, E., Birger, R., \& Lavee, S. (1994). Leaf spot (Spilocaea oleagina) of olive in Israel and its control. Acta Horticulturae, 356, 390-394.

Singleton, V. L., Orthofer, R., \& Lamuela-Raventos, R. M. (1999). Analysis of total phenols and other oxidation substrates and antioxidants by means of FolinCiocalteau reagent. Methods in Enzymology, 299, 152-178. 
Stenglein, S. A., Arambarri, A. M., Menendez Sevillano, M. C., \& Balatti, P. A. (2005). Leaf epidermal characters related with plant's passive resistance to pathogens vary among accessions of wild beans Phaseolus vulgaris var. aborigineus (Leguminosae-Phaseoleae). Flora, 200, 285-29.

Teviotdale, B. L., Sibbett, G. S., \& Harper, D. H. (1989). Control of olive leaf spot by copper fungicides. Applied Agricultural Research, 4, 185-189.

Trapero, A., \& Blanco, M. A. (2008). Enfermedades. In D. Barranco, R. Fernández-Escobar, \& L. Rallo (Eds.), El Cultivo de Olivo (pp. 557-614). Madrid: Coedición Junta de Andalucía/Mundi-Prensa.

Uccella, N. (2000). Olive biophenols: Biomolecular characterization, distribution and phytoalexin histochemical localization in the drupes. Trends in Food Science and Technology, 11, 315-327.

Vanneste, J. L., Voyle, M. D., Zydenbos, S. M. (2003). Genetic basis of copper resistance in New Zealand strains of Pseudomonas syringae. In 'New-Zealand-Plant-Protection.Proceedings-of-a conference,-Chateau-on-the-Park,Christchurch,-New-Zealand,-12-14-August-2003'. pp 109-112.
Viruega, J. R., Lique, F., \& Trapero, A. (1997). Caída de aceituhas debida a infectciones del pedunculo por Spilocaea oleagina, agente del Repilo del olivo. Fruticultura Professional, 88, 48-54.

Vossen, P. (2004). Timing sprays for control peacock spot and olive knot disease. Olive News University of California Cooperative Extension Glenn County. From http://www.oliveoilsource. com/peacock_spot,htm\#Timing.

Washington, W. S., Shanmuganathan, N., \& Forbes, C. (1992). Fungicide control of strawberry fruit rots and the field occurrence of resistance of Botrytis cinerea to iprodione, benomyl and dichlofluanid. Crop Protection, 11(4), 355360 .

Zaiter, H. Z., Coyne, D. P., Steadman, J. R., \& Beaver, J. S. (1990). Inheritance of abaxial leaf pubescence in beans. Journal of the American Society for Horticultural Science, $115,158-160$.

Zine El Aabidine, A., Baissac, Y., Moukhli, A., Jay-Allemand, C., Khadari, B., \& El Modafar, C. (2010). Resistance of olive-tree to Spilocaea oleagina is mediated by the synthesis of phenolic compounds. International Journal of Agriculture and Biology, 12, 61-67. 